\title{
Skład chemiczny wód podziemnych dopływających z Pobrzeża Kaszubskiego do Zatoki Puckiej
}

\author{
Dawid Potrykus ${ }^{1}$, Małgorzata Pruszkowska-Caceres ${ }^{1}$, Beata Jaworska-Szulc ${ }^{1}$, \\ Anna Gumuła-Kawęcka ${ }^{1}$, Adam Szymkiewicz ${ }^{1}$
}

\begin{abstract}
Chemical composition of groundwater discharged from the Kashubian Coast to the Bay of Puck. Prz. Geol., 68: 691-700; doi: $10.7306 / 2020.27$

A b s t r a c t. This study presents preliminary results of investigation of groundwater chemical composition (major ions, nitrogen and phosphorus compounds) in a coastal multi-aquifer groundwater system in the Puck Municipality. It was found that the groundwater composition is specific for each aquifer and shows some local variation. There is also a clear vertical geochemical inversion within the aquifers, with the highest concentrations of dissolved components in the shallowest aquifer. In general, all of the aquifers represent groundwater quality classes I, II and III, which can be evaluated as good quality according to Polish environmental law. An increase in the concentrations of principal pollution indicators over time has been observed only in the shallow aquifer. Distribution of basic pollution indicators in the groundwater implies a local impact of agriculture, as well as an influence of municipal wastes from households and farms. Poor sanitary conditions of farms, animal husbandry, storage and distribution of organic fertilizers (e.g. manure) can be potential sources of contamination. However, concentrations of contaminants in the coastal zone of aquifers discharging to the Bay of Puck are within the range for quality classes I and II, and generally lower than the concentrations measured in seawater, which suggests limited impact of the terrestrial groundwater discharge on the Bay of Puck contamination.
\end{abstract}

Keywords: groundwater contamination, agricultural pollution, nutrient compounds, Bay of Puck, coastal groundwater system

Zatoka Pucka jest płytkim akwenem morskim szczególnie wrażliwym na dopływ biogenów z otaczających obszarów lądowych. Postępujący problem eutrofizacji wód zatoki wymaga podjęcia działań badawczych i naprawczych, w tym również odpowiedzi na pytanie, czy i w jaki sposób spływające do zatoki wody podziemne wpływają na zjawisko eutrofizacji. Autorzy licznych prac naukowych zwracają uwagę, iż dopływ wód podziemnych do akwenów morskich (submarine groundwater discharge SGD), jest ważnym źródłem zanieczyszczenia wód morskich takimi składnikami jak: metale ciężkie, związki biogenne, węgiel nieorganiczny czy środki ochrony roślin (Slomp, Van Cappellen, 2004; Burnett i in., 2006; Moore, 2010; Lee i in., 2012; Bishop i in., 2017; Jiao, Post, 2019). Termin SGD odnosi się zarówno do dopływu wód podziemnych pochodzenia lądowego, jak i recyrkulacji wód pochodzenia morskiego w osadach dennych. Przeprowadzone dotąd badania na obszarze Zatoki Puckiej (Bolałek i in., 1993; Piekarek-Jankowska, 1994, 1996; Szymczycha i in., 2012, 2020) wskazują na znaczne zróżnicowanie jakości wód w obrębie akwenu, które może być związane z obecnością SGD. Niniejszy artykuł dotyczy jedynie wód podziemnych pochodzenia lądowego.

Celem przeprowadzonych badań, przedstawionych w tej publikacji, było określenie składu chemicznego wód podziemnych wraz z analizą ich jakości na wysoczyznowym obszarze Pobrzeża Kaszubskiego. Badane wody podziemne stanowią istotny składnik bilansu w zasilaniu Zatoki Puckiej, przez co mogą wpływać na obserwowany obecnie niezadawalający stan wód tego akwenu.

Zaprezentowane w artykule badania są częścią projektu finansowanego przez NCBiR - BIOSTRATEG III pt. Modelowanie wptywu gospodarstw rolnych i struktur użytkowania terenu zlewni na przykładzie gminy Puck na jakość wód ladowych i morskich zlokalizowanych w strefie przybrzeżnej Morza Baltyckiego - Zintegrowany Serwis Informacyjno-Predykcyjny WaterPUCK.

\section{CHARAKTERYSTYKA TERENU BADAŃ}

Badaniami objęto teren gminy Puck położony na wysoczyznowym obszarze Pobrzeża Kaszubskiego, który charakteryzuje się występowaniem dwóch zasadniczych form morfologicznych - wysoczyzny morenowej oraz pradolin. $\mathrm{Na}$ omawianym obszarze wysoczyzna morenowa tworzy kępy Swarzewską i Pucką, które graniczą z pradolinami Płutnicy i Kaszubską (Augustowski, 1977) (ryc. 1). Gospodarka regionu jest oparta na rolnictwie, rybołówstwie, przemyśle spożywczym i drzewnym, eksploatacji surowców skalnych, hodowli bydła i trzody chlewnej oraz turystyce. Obszar badań ma charakter rolniczo-leśny, gdzie tereny rolne zajmują ok. $65 \%$ powierzchni terenu, zaś lasy ok. 20\% (CLC2018, www.clc.gios.gov.pl). Na wysoczyźnie morenowej pola uprawne występują na glebach brunatnych i bielicowych, natomiast w dolinie rzek Płutnicy i Redy przeważają gleby pochodzenia organicznego (torfowe, glejowe i mady) pokryte łąkami (Gawlikowska i in., 2009). Na podstawie informacji uzyskanych z Urzędu Gminy Puck i własnych obserwacji terenowych można stwierdzić, że do lat 90. ub.w. w rolnictwie dominowała gospodarka, której podstawą były Państwowe Gospodarstwa Rolne. W Jastarni i Gdyni Dębogórzu istnieją oczyszczalnie ścieków, z których oczyszczone wody są odprowadzane do Zatoki Puckiej. Dopiero po 2014 r. siecią kanalizacyjną objęto prawie cały obszar gminy Puck, a w latach wcześniejszych powszechne były zbiorniki bezodpływowe (szamba), które w wielu miejscach istnieją do tej pory. W Łebczu, w wyrobisku dawnej żwirowni, istniało składowisko

\footnotetext{
${ }^{1}$ Wydział Inżynierii Lądowej i Środowiska, Politechnika Gdańska, ul. Narutowicza 11/12, 80-233 Gdańsk; dawpotry@pg.edu.pl; mpru@pg.edu.pl; bejaw@pg.edu.pl; annkawec@pg.edu.pl; adams@pg.edu.pl
} 


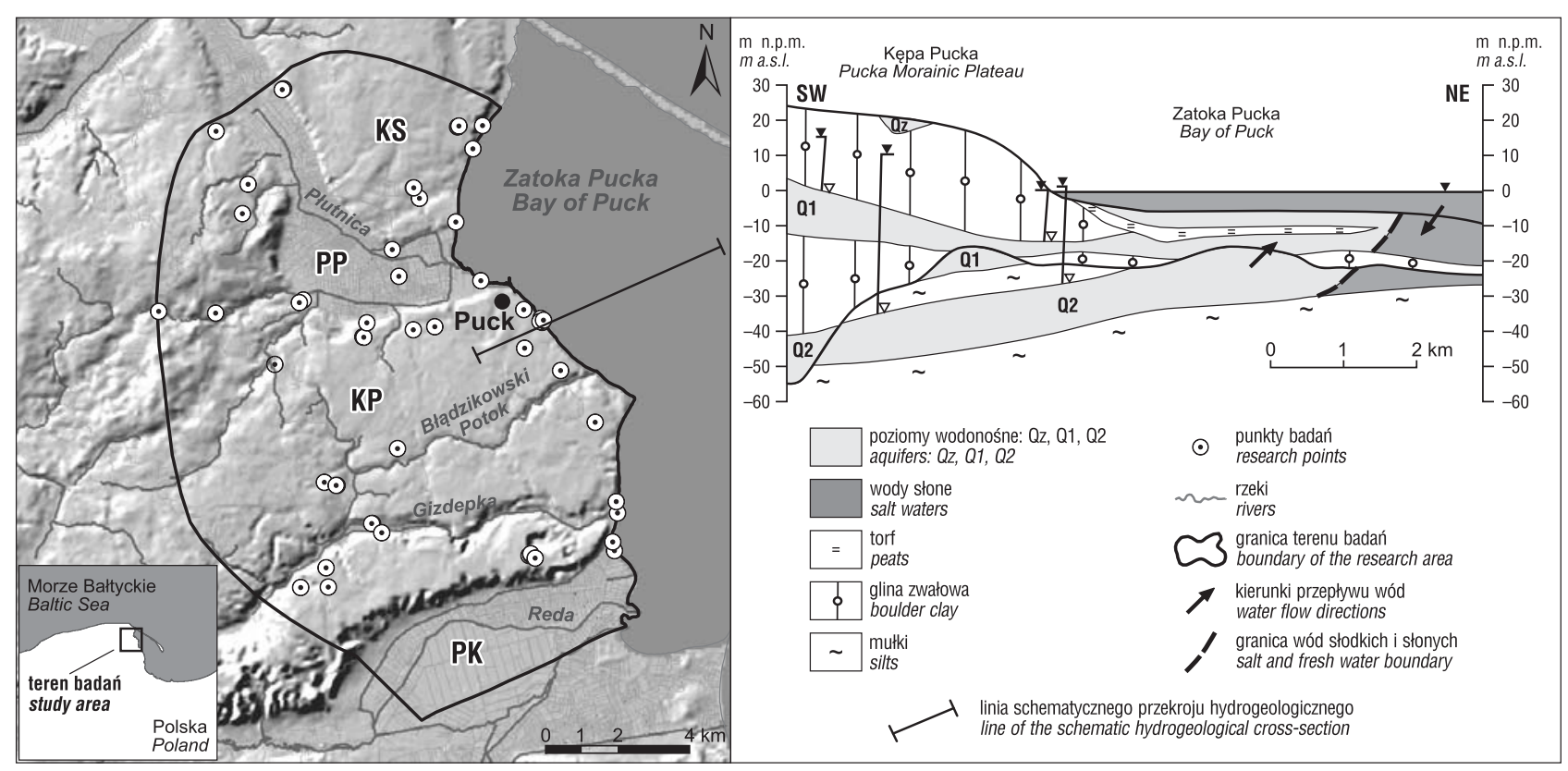

Ryc. 1. Lokalizacja i przekrój hydrogeologiczny terenu badań. KS - Kępa Swarzewska, PP - Pradolina Płutnicy, KP - Kępa Pucka, PK - Pradolina Kaszubska

Fig. 1. Location and hydrogeological cross-section of the investigation area. KS - Swarzewska Morainic Plateau, PP - Ice-Marginal Valley of the Płutnica River; KP - Pucka Morainic Plateau, PK - Kashubian Ice-Marginal Valley

odpadów komunalnych dla Pucka, Władysławowa oraz pozostałych okolicznych miejscowości, które aktualnie podlega rekultywacji.

W rejonie objętym badaniami można wydzielić dwa użytkowe poziomy wodonośne występujące w utworach czwartorzędu oraz neogenu. Mioceńska warstwa wodonośna ma charakter nieciągły i występuje na głębokościach od 50 do 30 m p.p.m., a na wyniesieniach podłoża czwartorzędowego podnosi się do 20 m n.p.m. (ryc. 1). Jej miąższość wynosi 5-20 m, a współczynnik filtracji waha się w granicach 0,04-0,33 m/h (Kryza, Kryza, 2006). Zwierciadło wody ma charakter subartezyjski i stabilizuje się na ok. 10-11 m n.p.m., w części wysoczyznowej obniżając się do 1-2 m n.p.m. w strefie brzegowej. Warstwa mioceńska kontaktuje się z wodami podziemnymi występującymi w utworach czwartorzędowych, często stanowiąc wspólny czwartorzędowo-neogeński poziom wodonośny nazwany poziomem podglinowym Q2 (ryc. 1) (Jankowska, 1993; Piekarek-Jankowska, 1994; Pruszkowska, 2005).

W osadach czwartorzędowych stopień zagrożenia antropogenicznego użytkowych poziomów wodonośnych na wysoczyźnie jest na ogół niski. Głębsza (podglinowa) warstwa wodonośna Q2 jest związana z piaszczysto-żwirowymi osadami zlodowacenia środkowopolskiego o miąższości do ok. $50 \mathrm{~m}$. Strop warstwy występuje na głębokości od 20 do $50 \mathrm{~m}$ p.p.m. (ryc. 1). Współczynnik filtracji dochodzi do 2,20 m/h. Płytszą (międzymorenową) warstwę wodonośną Q1 tworzą piaski i żwiry zalegające w obrębie glin zwałowych zlodowacenia wisły na głębokości od 30 m n.p.m. do 10 m p.p.m. (ryc. 1). Jej miąższość nie przekracza $20 \mathrm{~m}$, a współczynnik filtracji dochodzi do $1,60 \mathrm{~m} / \mathrm{h}$. Zwierciadło wody obu czwartorzędowych warstw wodonośnych stabilizuje na podobnym poziomie, w centralnej części kęp wysoczyznowych na ok. $15 \mathrm{~m}$ n.p.m. i 1-2 m n.p.m. w strefie brzegowej morza (Jankowska, 1993; Piekarek-Jankowska, 1994; Matciak i in., 2020; Szymkiewicz i in., 2020).
Lokalnie, na głębokościach 1-10 m p.p.t. występują soczewki wód zawieszonych Qz, najczęściej nie mające połączenia z płytszym, międzymorenowym poziomem wodonośnym (ryc. 1).

W pradolinach Kaszubskiej i Płutnicy występuje tylko jeden poziom wodonośny Q1, związany z osadami fluwioglacjalnymi oraz tarasów akumulacyjnych i stożków napływowych. Zwierciadło wód jest swobodne lub lekko napięte i znajduje się płytko pod powierzchnią terenu, najczęściej na głębokości 1-11 m, tj. 0,5-6 i 0,5-2 m n.p.m. w strefie brzegowej Zatoki Puckiej (ryc. 1) (Jankowska, 1993; Piekarek-Jankowska, 1994; Matciak i in., 2020). Jedyną izolacją warstwy wodonośnej jest kilkumetrowa pokrywa utworów organicznych (namułów i torfów), co wpływa na wysoki stopień zagrożenia antropogenicznego.

Drenaż wód podziemnych odbywa się w Zatoce Puckiej i ma charakter ascenzyjny. Pod dnem zatoki mają swą kontynuację wszystkie poziomy wodonośne, które są przykryte warstwa gliny zwałowej lub torfami i namułami (ryc. 1). Nadkład tych słabo przepuszczalnych utworów utrzymuje ciśnienie w warstwach wodonośnych, dzięki czemu granica rozdziału wód słodkich i słonych, a tym samym strefa drenażu jest przesunięta w kierunku morza na odległość 5-6 km od brzegu w Pradolinie Kaszubskiej i 2,5 km w Pradolinie Płutnicy oraz do 1,0 km od linii brzegu Kępy Swarzewskiej i do 2,5-4,0 km od brzegu Kępy Puckiej (Piekarek-Jankowska, 1994; Jankowska i in., 1994; Matciak i in., 2020; Szymkiewicz i in., 2020).

\section{METODYKA BADAŃ}

W ramach realizowanego projektu WaterPUCK wykonano szereg badań hydrogeologicznych, które przeprowadzono w okresie od lipca 2017 do czerwca 2019 r. Badania wykonano podczas 9 wizji terenowych, łącznie w 42 punktach wód podziemnych (studnie kopane, ujęcia indywidualne i komunalne oraz samowypływy) (ryc. 1). W ramach 
prac terenowych mierzono poziom zwierciadła wód podziemnych przy wykorzystaniu gwizdka hydrogeologicznego oraz oznaczano temperaturę, $\mathrm{pH}$, potencjał redoks (Eh), przewodność elektryczną właściwą (PEW) (140 analiz) przy użyciu miernika wieloparametrowego WTW Multi 3630 wraz z elektrodami SenTix ${ }^{\circledR}$ 950, SenTix ${ }^{\circledR}$ ORP-T 900 i TetraCon ${ }^{\circledR} 925$. Ponadto określono zawartość azotu (97 analiz $\mathrm{NH}_{4}^{+}$i $\mathrm{NO}_{3}^{-}$oraz 54 analizy $\mathrm{NO}_{2}^{-}$), fosforanów (83 analizy), siarczanów (97 analiz), chlorków (91 analiz), jonów potasu ( 73 analizy) oraz sodu ( 9 analiz) za pomoca fotometru WTW pHotoFlex STD wraz z odczynnikami.

$\mathrm{Z}$ reprezentatywnych, wybranych do projektu WaterPUCK 20 punktów badawczych, w laboratorium wykonywano dodatkowe oznaczenia $\mathrm{pH}, \mathrm{PEW}$, form azotu $\left(\mathrm{NH}_{4}^{+}\right.$, $\mathrm{NO}_{2}^{-}, \mathrm{NO}_{3}^{-}$, azot organiczny i ogólny), form fosforu ( $\mathrm{PO}_{4}^{3-}$, fosfor organiczny i ogólny), siarczanów, chlorków, jonów wapnia, magnezu, sodu, potasu, ChZT, twardości ogólnej oraz węglanowej dla wapnia i magnezu, a także zasadowości ogólnej. W 10 punktach zostały również dwukrotnie oznaczone zawartości pestycydów.

Zebrane w ramach projektu dane uzupełniono o wyniki wcześniejszych prac, prowadzonych od lat 60. XX w., łącznie 127 punktów badawczych. Do analizy wykorzystano głównie zestawienia tabelaryczne zawarte w objaśnieniach do map hydrogeologicznych (Frączek, 1998; Orłowski, 1998; Pasierowska, 2007; Nerkowski, 2010), dane z Centralnej Bazy Danych Hydrogeologicznych (CBDH) oraz udostępnione przez Urząd Gminy Puck wyniki analiz fizykochemicznych wód z ujęć komunalnych, dokumentacje hydrogeologiczne i operaty wodnoprawne.

Na podstawie analiz archiwalnych i wykonanych w ramach projektu (łącznie 409 analiz), zgodnie z metodyką określoną przez Macioszczyka (1990), opracowano współczesne i naturalne tło hydrogeochemiczne wraz $\mathrm{z}$ analizą zmienności składu chemicznego wód podziemnychw czasie. Uwzględniając lata wykonania studni oraz charakter zagospodarowania terenu i jego zmiany w czasie do wyznaczenia współczesnego, czyli aktualnego tła hydrogeochemicznego, wykorzystano analizy z lat 2010-2019 (łącznie 207 analiz), zaś tła naturalnego, czyli pierwotnego tła, nie zmienionego współczesną działalnością człowieka, wyniki z lat 1960-1990 (146 analiz). Były to również okresy o największej liczbie wykonanych analiz wód podziemnych.

Klasy jakości wód podziemnych, zgodnie z Rozporządzeniem Ministra Gospodarki Morskiej i Żeglugi Śródlądowej z dnia 11 października 2019 r. w sprawie kryteriów i sposobu oceny stanu jednolitych części wód podziemnych (Rozporządzenie, 2019), wyznaczono tylko dla wód pobranych w ramach projektu WaterPUCK, łącznie 160 analiz.

W ramach projektu został wykonany model hydrogeologiczny przepływu wód podziemnych z uwzględnieniem migracji zanieczyszczeń do wewnętrznej części Zatoki Puckiej (Szymkiewicz i in., 2020). Zaprezentowane w niniejszym artykule badania posłużyły do opracowania wspomnianego modelu transportu zanieczyszczeń oraz jego kalibracji.

W tekście omówiono jedynie wybrane wyniki przeprowadzonych badań, zdaniem autorów najistotniejsze ze względu na poruszoną problematykę jakości wód podziemnych dopływających z badanego obszaru Pobrzeża Kaszubskiego do Zatoki Puckiej. Pełen zakres danych hy- drogeologicznych zebranych na potrzeby realizacji projektu WaterPUCK jest dostępny w formie bazy danych na stronie projektu (www.waterpuck.pl).

\section{WYNIKI BADAŃ}

Zakresy stężeń oraz tło hydrogeochemiczne wybranych, analizowanych w artykule parametrów hydrogeochemicznych decydujących o jakości wód podziemnych, z podziałem na poziomy wodonośne, z okresu 1960-2019 zestawiono w tabeli 1. Ilość oznaczeń analizowanych elementów fizykochemicznych z badań własnych (2017-2019) mieszczących się w poszczególnych poziomach wodonośnych i klasach jakości wód podziemnych (zgodnie z Rozporządzeniem, 2019) podano w tabeli 2. Różne ilości oznaczeń w danym poziomie wynikają z założeń realizowanego projektu WaterPUCK, uzależniających charakter analizy od zagospodarowania terenu i położenia punktu badawczego względem brzegu morza oraz z dostępności punktów badawczych podczas kampanii terenowych.

Wody podziemne wykazują zróżnicowane przewodnictwo elektrolityczne, które waha się w zakresie 124$1346 \mu \mathrm{S} / \mathrm{cm}$, wskazując na lokalną obecność substancji zanieczyszczających. W miejscach tych, w poziomie Qz i Q1 (tab. 1 i 2), przewodnictwo przybiera wartości wyższe niż $700 \mu \mathrm{S} / \mathrm{cm}$, czyli powyżej I klasy jakości wód podziemnych.

Zakres zmienności związków azotu jest bardzo szeroki. Stężenia jonu amonowego wahają się w granicach 0,013,56 $\mathrm{mgNH}_{4} / \mathrm{l}$, co odpowiada I-V klasie jakości wód (poziomy Qz i Q1). Zakres stężeń azotynów wynosi 0,00-0,67 $\mathrm{mgNO}_{2} / 1$ (klasy jakości I-IV), a azotany występują w ilościach do $92,0 \mathrm{mgNO}_{3} / \mathrm{l} \mathrm{w}$ poziomie Q1 (klasy I-IV). Stężenia fosforanów w badanych wodach są niewielkie i występują najczęściej w zakresie klasy I i II, czyli $<0,50 \mathrm{mgPO}_{4} / 1$. Tylko lokalnie wzrastają do $6,38 \mathrm{mgPO}_{4} / 1$ (klasa V) w poziomie Qz i 3,06 mgPO $/$ l (klasa IV) w Q1. Stężenia siarczanów sięgają $156 \mathrm{mgSO}_{4} / 1$, co odpowiada I i II klasie jakości wód. Chlorki występują w ilościach do $158 \mathrm{mgCl} / 1$, zaś sód do 96,0 mgNa/1, co odpowiada I oraz II klasie jakości wód podziemnych. Jony potasu najczęściej nie przekraczają kilku mgK/l, jednak lokalnie ich stężenie podnosi się powyżej 10,0 $\mathrm{mgK} / 1$, a nawet do $96,5 \mathrm{mgK} / 1$, co wiąże się z zanieczyszczeniem i odpowiada III, IV oraz V klasie jakości wód (poziomy Qz i Q1) (tab. 1 i 2).

Pestycydy wykryto jedynie w dwóch punktach w wodach zawieszonych. Był to kwas aminometylofosfonowy AMPA wstężeniu $0,11 \mu \mathrm{g} / 1$ oraz glifosat $0,021 \mu \mathrm{g} / \mathrm{l}$.

Wody podziemne dopływające do Zatoki Puckiej, wg klasyfikacji stanu chemicznego, charakteryzują się dobrym stanem chemicznym (Rozporządzenie, 2019). W górnym poziomie wodonośnym (Q1) większość badanych parametrów odpowiada I, II lub III klasie jakości (wody bardzo dobrej, dobrej i zadawalającej jakości). Parametry odpowiadające IV i V klasie (wody niezadowalającej i słabej jakości) stwierdzono w górnym poziomie jedynie punktowo: 3 z 77 próbek wykazywało IV klasę jakości ze względu na zawartość azotanów, 8 z 64 ze względu na zawartość fosforanów, a 6 z 58 próbek wykazywało V klasę jakości ze względu na zawartość potasu (tab. 2). W dolnym poziomie wodonośnym (Q2) wszystkie badane parametry jakości wód odpowiadały I lub II klasie jakości wód. 
Tab. 1. Wybrane parametry hydrogeochemiczne wód podziemnych wydzielonych poziomów wodonośnych (Qz, Q1, Q2) z lat 1960-2019

Table 1. Selected hydrogeochemical parameters in the aquifers Qz, Q1 and Q2 (sampling period 1960-2019)

\begin{tabular}{|c|c|c|c|c|c|c|}
\hline & \multicolumn{2}{|c|}{$\begin{array}{l}\text { Wody zawieszone } Q \mathrm{z} \\
\text { Perched aquifer } Q z\end{array}$} & \multicolumn{2}{|c|}{$\begin{array}{c}\text { Poziom wodonośny Q1 } \\
\text { Upper aquifer } Q 1\end{array}$} & \multicolumn{2}{|c|}{$\begin{array}{l}\text { Poziom wodonośny } Q 2 \\
\text { Lower aquifer } Q_{2}^{2}\end{array}$} \\
\hline & $\min .-\max$ & $\begin{array}{l}\text { współczesne t. h. } \\
\text { contemporary } h . b .\end{array}$ & min.-max. & $\begin{array}{l}\text { współczesne t. h. } \\
\text { contemporary } h . b .\end{array}$ & min.-max. & $\begin{array}{l}\text { współczesne t. h. } \\
\text { contemporary } h . b \text {. }\end{array}$ \\
\hline & $\begin{array}{l}\text { mediana } \\
\text { median }\end{array}$ & $\begin{array}{l}\text { naturalne t. h. } \\
\text { natural h. } b .\end{array}$ & $\begin{array}{l}\text { mediana } \\
\text { median }\end{array}$ & $\begin{array}{l}\text { naturalne t. h. } \\
\text { natural } h . b .\end{array}$ & $\begin{array}{l}\text { mediana } \\
\text { median }\end{array}$ & $\begin{array}{l}\text { naturalne t. h. } \\
\text { natural } h . b .\end{array}$ \\
\hline \multirow{2}{*}{$\begin{array}{l}\mathrm{PEW} \\
{[\mu \mathrm{S} / \mathrm{cm}]}\end{array}$} & 124-1346 & $300-570$ & $244-1012$ & $370-870$ & $279-680$ & $320-600$ \\
\hline & 491 & - & 572 & $380-620$ & 432 & $380-520$ \\
\hline \multirow{2}{*}{$\begin{array}{l}\mathrm{NH}_{4}^{+} \\
{[\mathrm{mg} / \mathrm{l}]}\end{array}$} & $<0,01-3,56$ & $0,00-0,10$ & $<0,01-3,32$ & $0,00-0,20$ & $<0,01-0,37$ & $0,00-0,75$ \\
\hline & 0,03 & - & 0,03 & $0,00-0,30$ & 0,14 & $0,00-0,75$ \\
\hline \multirow{2}{*}{$\begin{array}{l}\mathrm{NO}_{2}^{-} \\
{[\mathrm{mg} / \mathrm{l}]}\end{array}$} & $<0,01-0,67$ & $0,00-0,04$ & $<0,01-0,42$ & $0,00-0,02$ & $<0,01-0,09$ & $0,00-0,02$ \\
\hline & 0,04 & - & 0,01 & $0,00-0,02$ & $<0,01$ & $0,00-0,02$ \\
\hline \multirow{2}{*}{$\begin{array}{l}\mathrm{NO}_{3}^{-} \\
{[\mathrm{mg} / \mathrm{l}]}\end{array}$} & $2,0-49,0$ & $30,0-22,0$ & $<0,1-92,0$ & $0,0-2,5$ & $<0,1-1,0$ & $0,0-0,7$ \\
\hline & 26,0 & - & 10,0 & $0,0-2,0$ & 0,3 & $0,0-0,5$ \\
\hline \multirow{2}{*}{$\begin{array}{l}\mathrm{PO}_{4}^{3-} \\
{[\mathrm{mg} / \mathrm{I}]}\end{array}$} & $0,16-6,38$ & $0,15-0,75$ & $0,10-3,06$ & $0,10-0,50$ & $0,09-0,49$ & $0,10-0,30$ \\
\hline & 0,50 & - & 0,37 & - & 0,14 & - \\
\hline \multirow{2}{*}{$\begin{array}{l}\mathrm{SO}_{4}^{2-} \\
{[\mathrm{mg} / \mathrm{l}]}\end{array}$} & $5-89$ & $5-60$ & $2-156$ & $5-55$ & $4-143$ & $2-38$ \\
\hline & 29 & - & 45 & $0-35$ & 17 & $0-50$ \\
\hline \multirow{2}{*}{$\begin{array}{l}\mathrm{Cl}^{-} \\
{[\mathrm{mg} / \mathrm{l}]}\end{array}$} & $1,4-158,0$ & $2,0-22,0$ & $1,0-100,0$ & $0,0-55,0$ & $1,0-21,3$ & $0,0-18,0$ \\
\hline & 13,2 & - & 16,6 & $0,0-35,0$ & 7,4 & $0,0-18,0$ \\
\hline \multirow{2}{*}{$\begin{array}{l}\mathbf{K}^{+} \\
{[\mathrm{mg} / \mathrm{l}]}\end{array}$} & $1,1-96,5$ & $0,0-6,0$ & $0,4-29,1$ & $0,0-6,0$ & $0,6-3,5$ & $0,0-4,5$ \\
\hline & 9,1 & - & 3,1 & - & 2,0 & - \\
\hline \multirow{2}{*}{$\begin{array}{l}\mathrm{Na}^{+} \\
{[\mathrm{mg} / \mathrm{I}]}\end{array}$} & $8,5-95,7$ & - & $4,9-74,9$ & - & - & - \\
\hline & 12,7 & $1-60 *$ & 13,4 & $1-60 *$ & - & $1-60 *$ \\
\hline
\end{tabular}

t. h. - tło hydrogeochemiczne / h. b. - hydrogeochemical background.

* Tło hydrogeochemiczne wg Witczaka, Adamczyka (1995) / Hydrogeochemical background acc. to Witczak, Adamczyk (1995).

\section{DYSKUSJA WYNIKÓW}

Analizując wyniki badań, można uznać, iż skład chemiczny wydzielonych poziomów wodonośnych jest zbliżony. Wykazuje jednak zmienność parametrów hydrogeochemicznych w czasie, a także wraz ze wzrostem głębokości występowania wód podziemnych oraz mozaikowy rozkład przestrzenny.

Wyraźne zróżnicowanie składu chemicznego w czasie jest zauważalne w wodach podziemnych płytko położonych poziomów wodonośnych, które dodatkowo nie posiadaja odpowiedniej izolacji od powierzchni terenu. Poziomy te, przy możliwym dopływie zanieczyszczeń z powierzchni terenu, są szczególnie narażone na długotrwałe zmiany jakości wód podziemnych. Obecnie obserwuje się wyższe stężenia jonów $\mathrm{NO}_{3}^{-}$i PEW w poziomie Q1 niż miało to miejsce w poprzednich latach (ryc. 2).

Należy jednak zauważyć, że wyznaczone zakresy naturalnego i współczesnego tła hydrogeochemicznego są na ogół zgodne. Niewielkie przesunięcia tła ku wyższym wartościom stwierdzono tylko w przypadku PEW, chlorków i siarczanów w poziomie Q1 oraz $\mathrm{NO}_{2}^{-}$i $\mathrm{NO}_{3}^{-}$w poziomie Q2 (tab. 1).

Istotnym elementem oceny warunków hydrogeochemicznych jest głębokość występowania wód podziemnych. Wiąże się z nią miąższość i charakter nadkładu utworów wodonośnych, sposób ich zasilania, kontakt hydrauliczny z wodami powierzchniowymi oraz czas przebywania wody w środowisku skalnym. Na rycinie 3 przedstawiono zależność stężeń wybranych parametrów hydrochemicznych od głębokości występowania wód podziemnych, w okresie od 2017 do 2019 r. Najwyższe stężenia stwierdzono w najpłytszych wodach zawieszonych oraz płytkich, nieizolowanych od powierzchni terenu wodach poziomu Q1, które występują na głębokości do ok. $20 \mathrm{~m}$ p.p.t. Tendencja ta jest również widoczna w przypadku mediany (ryc. 3, tab. 1 i 2). Wyjątkiem są wysokie zawartości jonów $\mathrm{NO}_{3}^{-}$w poziomie Q1 i SO ${ }_{4}^{2-}$ w poziomach Q1 i Q2, a także wzrost mediany $\mathrm{NH}_{4}^{+}$w Q2, co wiąże się z warunkami środowiska wodonośnego oraz możliwym lokalnym zanieczyszczeniem. Stężenia pozostałych analizowanych parametrów maleją wraz ze wzrostem głębokości, co jest określane mianem inwersji hydrogeochemicznej.

W gminie Puck zaznacza się również wyraźne zróżnicowanie przestrzenne - tzw. mozaikowa zmienność składu chemicznego wód podziemnych (tab. 2, ryc. 4), dotyczy ona zwłaszcza dobrze migrujących $\mathrm{w}$ wodach podziemnych jonów, na przykład chlorków i $\mathrm{NO}_{3}^{-}$.

Na rycinie 4 pokazano rozkład przestrzenny podwyższonych i wysokich stężeń analizowanych parametrów hydrogeochemicznych w wydzielonych poziomach wodonośnych na tle mapy stopnia podatności na zanieczyszczenie pierwszego poziomu wodonośnego opracowanej przez Pasierowską (2007) oraz Sierżęgę i Nerkowskiego (2010). Na mapie przedstawiono tylko punkty, w których parametry chemiczne wód podziemnych przekroczyły normy dla I klasy jakości zgodnie z rozporządzeniem (2019). W poszczególnych punktach uwzględniono jedynie parametry, które wykazały największe przekroczenia $\mathrm{w}$ badaniach terenowych w okresie 2017-2019, tj. jeśli wskaźniki $\mathrm{NH}_{4}^{+}, \mathrm{PO}_{4}^{3-}$ i $\mathrm{K}^{+}$znajdują się w V klasie, a $\mathrm{NO}_{2}^{-}$w III klasie, to wody 
Tab. 2. Ilość oznaczeń elementów fizykochemicznych w wodach podziemnych w poszczególnych klasach jakości wód podziemnych (zgodnie z Rozporządzeniem, 2019) z lat 2017-2019

Table 2. Number of groundwater samples with physicochemical indices corresponding to each quality class (acc. to Rozporządzenie, 2019) (sampling period 2017-2019)

\begin{tabular}{|c|c|c|c|c|c|c|c|c|c|c|}
\hline & $\begin{array}{l}\text { Parametr } \\
\text { Parameter }\end{array}$ & $\begin{array}{c}\text { PEW } \\
{[\mu \mathrm{S} / \mathrm{cm}]}\end{array}$ & $\begin{array}{c}\mathrm{NH}_{4}^{+} \\
{[\mathrm{mg} / \mathrm{l}]}\end{array}$ & $\begin{array}{c}\mathrm{NO}_{2}^{-} \\
{[\mathrm{mg} / \mathrm{l}]}\end{array}$ & $\begin{array}{c}\mathrm{NO}_{3}^{-} \\
{[\mathrm{mg} / \mathrm{l}]}\end{array}$ & $\begin{array}{l}\mathrm{PO}_{4}^{3-} \\
{[\mathrm{mg} / \mathrm{l}]}\end{array}$ & $\begin{array}{c}\mathrm{SO}_{4}^{2-} \\
{[\mathrm{mg} / \mathrm{l}]}\end{array}$ & $\begin{array}{c}\mathrm{Cl}^{-} \\
{[\mathrm{mg} / \mathrm{l}]}\end{array}$ & $\begin{array}{c}\mathbf{K}^{+} \\
{[\mathbf{m g} / \mathbf{l}]}\end{array}$ & $\begin{array}{c}\mathrm{Na}^{+} \\
{[\mathrm{mg} / \mathrm{l}]}\end{array}$ \\
\hline $\mathrm{Qz}$ & $\mathrm{nQz}=30$ & 30 & 24 & 15 & 24 & 24 & 24 & 24 & 21 & 7 \\
\hline \multirow{3}{*}{$\begin{array}{l}\text { Stan dobry } \\
\text { Good water } \\
\text { quality }\end{array}$} & $\begin{array}{l}\text { I klasa } \\
\text { class I }\end{array}$ & $\begin{array}{c}18 \\
(700)\end{array}$ & $\begin{array}{c}19 \\
(0,5)\end{array}$ & $\begin{array}{c}5 \\
(0,03)\end{array}$ & $\begin{array}{c}6 \\
(10) \\
\end{array}$ & $\begin{array}{c}12 \\
(0,5)\end{array}$ & $\begin{array}{c}23 \\
(60)\end{array}$ & $\begin{array}{c}19 \\
(60)\end{array}$ & $\begin{array}{c}10 \\
(10)\end{array}$ & $\begin{array}{c}6 \\
(60) \\
\end{array}$ \\
\hline & $\begin{array}{l}\text { II klasa } \\
\text { class II }\end{array}$ & $\begin{array}{c}12 \\
(2500)\end{array}$ & $\begin{array}{c}1 \\
(1,0)\end{array}$ & $\begin{array}{c}6 \\
(0,15) \\
\end{array}$ & $\begin{array}{c}5 \\
(25) \\
\end{array}$ & $\begin{array}{c}0 \\
(0,5) \\
\end{array}$ & $\begin{array}{c}1 \\
(250) \\
\end{array}$ & $\begin{array}{c}4 \\
(150) \\
\end{array}$ & $\begin{array}{c}0 \\
(10) \\
\end{array}$ & $\begin{array}{c}1 \\
(200) \\
\end{array}$ \\
\hline & $\begin{array}{l}\text { III klasa } \\
\text { class III }\end{array}$ & $\begin{array}{c}0 \\
(2500)\end{array}$ & $\begin{array}{c}0 \\
(1,5)\end{array}$ & $\begin{array}{c}2 \\
(0,50)\end{array}$ & $\begin{array}{c}13 \\
(50)\end{array}$ & $\begin{array}{c}6 \\
(1,0)\end{array}$ & $\begin{array}{c}0 \\
(250)\end{array}$ & $\begin{array}{c}1 \\
(250)\end{array}$ & $\begin{array}{c}4 \\
(15)\end{array}$ & $\begin{array}{c}0 \\
(200)\end{array}$ \\
\hline \multirow{2}{*}{$\begin{array}{l}\text { Stan słaby } \\
\text { Poor water } \\
\text { quality }\end{array}$} & $\begin{array}{l}\text { IV klasa } \\
\text { class IV }\end{array}$ & $\begin{array}{c}0 \\
(3000)\end{array}$ & $\begin{array}{c}3 \\
(3,0) \\
\end{array}$ & $\begin{array}{c}2 \\
(1,00)\end{array}$ & $\begin{array}{c}0 \\
(100)\end{array}$ & $\begin{array}{c}2 \\
(5,0)\end{array}$ & $\begin{array}{c}0 \\
(500)\end{array}$ & $\begin{array}{c}0 \\
(500)\end{array}$ & $\begin{array}{c}2 \\
(20) \\
\end{array}$ & $\begin{array}{c}0 \\
(300)\end{array}$ \\
\hline & $\begin{array}{l}\text { V klasa } \\
\text { class } V\end{array}$ & $\begin{array}{c}0 \\
(>3000) \\
\end{array}$ & $\begin{array}{c}1 \\
(>3,0)\end{array}$ & $\begin{array}{c}0 \\
(>1,00)\end{array}$ & $\begin{array}{c}0 \\
(>100)\end{array}$ & $\begin{array}{c}4 \\
(>5,0) \\
\end{array}$ & $\begin{array}{c}0 \\
(>500) \\
\end{array}$ & $\begin{array}{c}0 \\
(>500)\end{array}$ & $\begin{array}{c}5 \\
(>20) \\
\end{array}$ & $\begin{array}{c}0 \\
(>300) \\
\end{array}$ \\
\hline Q1 & $\mathrm{nQ1}=95$ & 95 & 77 & 47 & 77 & 64 & 77 & 72 & 58 & 22 \\
\hline \multirow{3}{*}{$\begin{array}{l}\text { Stan dobry } \\
\text { Good water } \\
\text { quality }\end{array}$} & $\begin{array}{l}\text { I klasa } \\
\text { class I }\end{array}$ & $\begin{array}{c}77 \\
(700)\end{array}$ & $\begin{array}{c}73 \\
(0,5)\end{array}$ & $\begin{array}{c}33 \\
(0,03)\end{array}$ & $\begin{array}{c}40 \\
(10)\end{array}$ & $\begin{array}{c}38 \\
(0,5)\end{array}$ & $\begin{array}{c}43 \\
(60)\end{array}$ & $\begin{array}{c}68 \\
(60)\end{array}$ & $\begin{array}{c}50 \\
(10)\end{array}$ & $\begin{array}{c}21 \\
(60)\end{array}$ \\
\hline & \begin{tabular}{|l|} 
II klasa \\
class II
\end{tabular} & $\begin{array}{c}18 \\
(2500)\end{array}$ & $\begin{array}{c}2 \\
(1,0)\end{array}$ & $\begin{array}{c}11 \\
(0,15)\end{array}$ & $\begin{array}{c}26 \\
(25)\end{array}$ & $\begin{array}{c}0 \\
(0,5)\end{array}$ & $\begin{array}{c}34 \\
(250)\end{array}$ & $\begin{array}{c}4 \\
(150)\end{array}$ & $\begin{array}{c}0 \\
10) \\
\end{array}$ & $\begin{array}{c}1 \\
(200)\end{array}$ \\
\hline & $\begin{array}{l}\text { III klasa } \\
\text { class III }\end{array}$ & $\begin{array}{c}0 \\
(2500) \\
\end{array}$ & $\begin{array}{c}2 \\
(1,5)\end{array}$ & $\begin{array}{c}3 \\
(0,50)\end{array}$ & $\begin{array}{c}8 \\
(50) \\
\end{array}$ & $\begin{array}{c}18 \\
(1,0)\end{array}$ & $\begin{array}{c}0 \\
(250)\end{array}$ & $\begin{array}{c}0 \\
(250)\end{array}$ & $\begin{array}{c}2 \\
(15)\end{array}$ & $\begin{array}{c}0 \\
(200)\end{array}$ \\
\hline \multirow{2}{*}{$\begin{array}{l}\text { Stan słaby } \\
\text { Poor water } \\
\text { quality }\end{array}$} & $\begin{array}{l}\text { IV klasa } \\
\text { class IV }\end{array}$ & $\begin{array}{c}0 \\
(3000)\end{array}$ & $\begin{array}{c}0 \\
(3,0)\end{array}$ & $\begin{array}{c}0 \\
(1,00)\end{array}$ & $\begin{array}{c}3 \\
(100)\end{array}$ & $\begin{array}{c}8 \\
(5,0) \\
\end{array}$ & $\begin{array}{c}0 \\
(500) \\
\end{array}$ & $\begin{array}{c}0 \\
(500)\end{array}$ & $\begin{array}{c}0 \\
(20) \\
\end{array}$ & $\begin{array}{c}0 \\
(300)\end{array}$ \\
\hline & $\begin{array}{l}\text { V klasa } \\
\text { class } V\end{array}$ & $\begin{array}{c}0 \\
(>3000)\end{array}$ & $\begin{array}{c}0 \\
(>3,0)\end{array}$ & $\begin{array}{c}0 \\
(>1,00)\end{array}$ & $\begin{array}{c}0 \\
(>100)\end{array}$ & $\begin{array}{c}0 \\
(>5,0)\end{array}$ & $\begin{array}{c}0 \\
(>500)\end{array}$ & $\begin{array}{c}0 \\
(>500)\end{array}$ & $\begin{array}{c}0 \\
(>20)\end{array}$ & $\begin{array}{c}0 \\
(>300)\end{array}$ \\
\hline Q2 & $\mathrm{nQ} 2=35$ & 35 & 16 & 12 & 16 & 15 & 16 & 15 & 14 & 0 \\
\hline \multirow{3}{*}{$\begin{array}{l}\text { Stan dobry } \\
\text { Good water } \\
\text { quality }\end{array}$} & $\begin{array}{l}\text { I klasa } \\
\text { class I }\end{array}$ & $\begin{array}{c}35 \\
(700)\end{array}$ & $\begin{array}{c}16 \\
(0,5) \\
\end{array}$ & $\begin{array}{c}8 \\
(0,03)\end{array}$ & $\begin{array}{c}16 \\
(10)\end{array}$ & $\begin{array}{c}15 \\
(0,5) \\
\end{array}$ & $\begin{array}{c}15 \\
(60) \\
\end{array}$ & $\begin{array}{c}15 \\
(60) \\
\end{array}$ & $\begin{array}{c}14 \\
(10)\end{array}$ & - \\
\hline & \begin{tabular}{|l|} 
II klasa \\
class II
\end{tabular} & $\begin{array}{c}0 \\
(2500) \\
\end{array}$ & $\begin{array}{c}0 \\
(1,0)\end{array}$ & $\begin{array}{c}4 \\
(0,15) \\
\end{array}$ & $\begin{array}{c}0 \\
(25) \\
\end{array}$ & $\begin{array}{c}0 \\
(0,5) \\
\end{array}$ & $\begin{array}{c}1 \\
(250) \\
\end{array}$ & $\begin{array}{c}0 \\
(150)\end{array}$ & $\begin{array}{c}0 \\
(10) \\
\end{array}$ & - \\
\hline & $\begin{array}{l}\text { III klasa } \\
\text { class III }\end{array}$ & $\begin{array}{c}0 \\
(2500)\end{array}$ & $\begin{array}{c}0 \\
(1,5)\end{array}$ & $\begin{array}{c}0 \\
(0,50)\end{array}$ & $\begin{array}{c}0 \\
(50) \\
\end{array}$ & $\begin{array}{c}0 \\
(1,0)\end{array}$ & $\begin{array}{c}0 \\
(250)\end{array}$ & $\begin{array}{c}0 \\
(250)\end{array}$ & $\begin{array}{c}0 \\
(15) \\
\end{array}$ & - \\
\hline \multirow{2}{*}{$\begin{array}{l}\text { Stan słaby } \\
\text { Poor water } \\
\text { quality }\end{array}$} & $\begin{array}{l}\text { IV klasa } \\
\text { class IV }\end{array}$ & $\begin{array}{c}0 \\
(3000)\end{array}$ & $\begin{array}{c}0 \\
(3,0)\end{array}$ & $\begin{array}{c}0 \\
(1,00)\end{array}$ & $\begin{array}{c}0 \\
(100)\end{array}$ & $\begin{array}{c}0 \\
(5,0)\end{array}$ & $\begin{array}{c}0 \\
(500)\end{array}$ & $\begin{array}{c}0 \\
(500)\end{array}$ & $\begin{array}{c}0 \\
(20)\end{array}$ & - \\
\hline & $\begin{array}{l}\text { V klasa } \\
\text { class } V\end{array}$ & $\begin{array}{c}0 \\
(>3000)\end{array}$ & $\begin{array}{c}0 \\
(>3,0)\end{array}$ & $\begin{array}{c}0 \\
(>1,00)\end{array}$ & $\begin{array}{c}0 \\
(>100)\end{array}$ & $\begin{array}{c}0 \\
(>5,0)\end{array}$ & $\begin{array}{c}0 \\
(>500)\end{array}$ & $\begin{array}{c}0 \\
(>500)\end{array}$ & $\begin{array}{c}0 \\
(>20)\end{array}$ & - \\
\hline
\end{tabular}

W nawiasach podano maksymalne wartości graniczne parametrów hydrogeochemicznych w poszczególnych klasach jakości wód podziemnych zgodnie z Rozporządzeniem (2019).

In brackets: maximum limit values of hydrogeochemical parameters in the individual classes of groundwater quality acc. to Rozporzadzenie (2019).

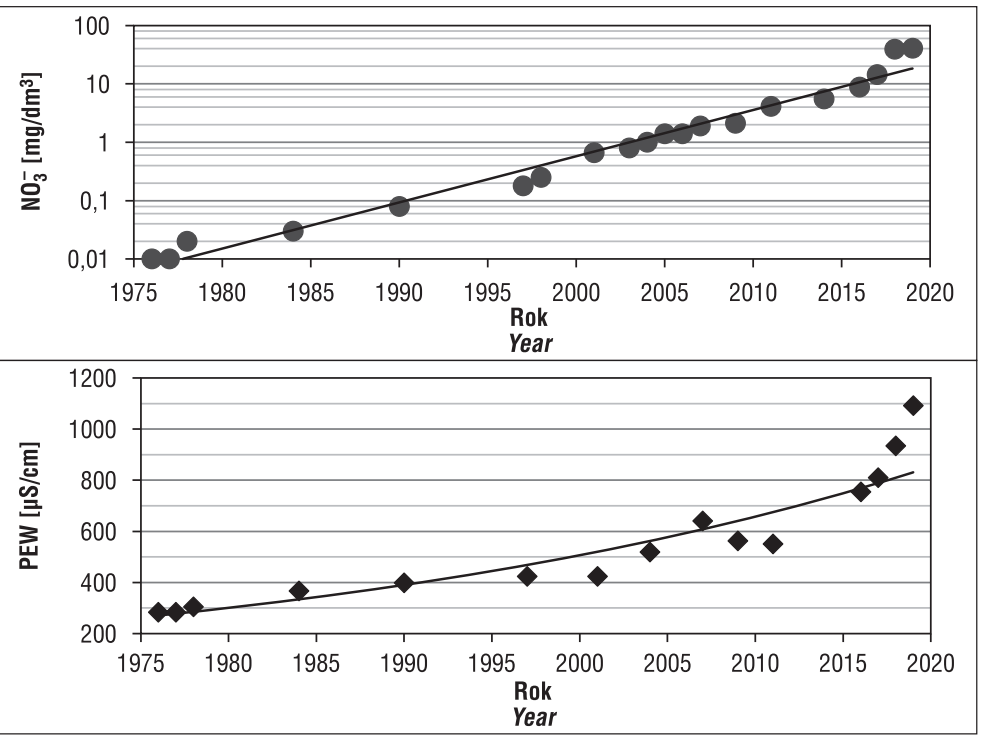

Ryc. 2. Czasowa zmienność maksymalnych stężeń $\mathrm{NO}_{3}^{-} \mathrm{i}$ PEW w poziomie Q1

Fig. 2. Time variability of $\mathrm{PEW}$ and $\mathrm{NO}_{3}^{-}$maximum concentrations in the $\mathrm{Q} 1$ aquifer w tym punkcie zostały przedstawione jako wody odpowiadające $\mathrm{V}$ klasie i podano tylko wskaźniki z tej klasy.

Otwory, w których stwierdzono podwyższone stężenia parametrów chemicznych, są rozproszone w obrębie omawianego obszaru, co świadczy o tym, że pochodzą one z ognisk zanieczyszczeń o lokalnym charakterze.

Podatność naturalna wód podziemnych jest determinowana wyłącznie warunkami hydrogeologicznymi systemu wodonośnego (Krogulec, 2006). Do podstawowych czynników kształtujących stopień podatności wód podziemnych na analizowanym obszarze należą miąższość i wykształcenie litologiczne utworów przykrywających. Na mapie (ryc. 4) zostało wydzielonych pięć klas podatności, w których przepływ potencjalnych zanieczyszczeń z powierzchni terenu do warstw wodonośnych trwa odpowiednio: podatność bardzo niska (>100 lat), niska (50-100 lat), średnia (25-50 lat), wysoka (5-25 lat), 


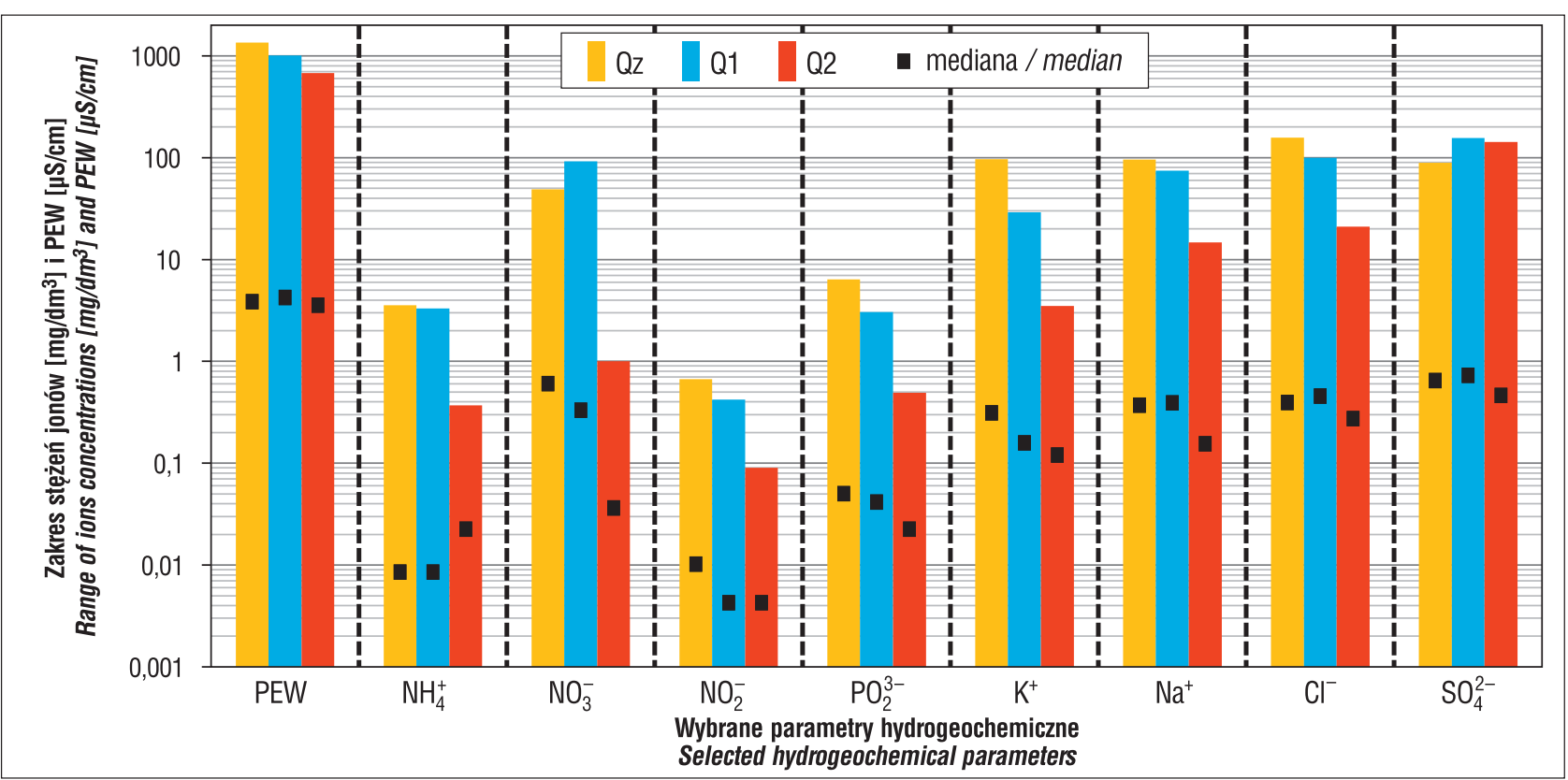

Ryc. 3. Zależność stężeń wybranych parametrów hydrogeochemicznych od głębokości występowania wód podziemnych (dane z lat 2017-2019)

Fig. 3. Relationship between the concentrations of selected hydrogeochemical parameters and the depth to aquifer (sampling period 2017-2019)

bardzo wysoka (<5 lat). Czas migracji przez strefę aeracji został obliczony w oparciu o algorytm MRT (mean residence time), który określa średni czas wymiany wilgotności objętościowej gleb i skał strefy aeracji przez infiltrujące wody opadowe (Herbich i in., 2007). Obszary o bardzo wysokim i wysokim stopniu podatności wód podziemnych na zanieczyszczenia występują w obrębie pradolin Płutnicy i Kaszubskiej, doliny Gizdepki, obszarów sandrowych w zachodniej części analizowanego obszaru oraz strefy przybrzeżnej na Kępie Puckiej (ryc. 4). W rejonach tych głębokość do pierwszego poziomu wodonośnego zazwyczaj nie przekracza $5 \mathrm{~m}$, a utwory strefy nienasyconej stanowią osady dobrze lub półprzepuszczalne: piaski i żwiry wodnolodowcowe oraz torfy, namuły i piaski humusowe den dolin. Wraz ze wzrostem głębokości do wód podziemnych zmniejsza się stopień podatności poziomu wodonośnego. Obszary o średnim stopniu podatności znajdują się w strefach krawędziowych kęp oraz na terenach o niewielkim udziale utworów słabo przepuszczalnych (piaski wodnolodowcowe i eluwialne na glinach), położonych we wschodniej części badanego obszaru i w rejonie doliny Błądzikowskiego Potoku. Na pozostałym terenie występują obszary o niskim i bardzo niskim stopniu podatności. Wynika to z występowania utworów słabo przepuszczalnych, głównie gliny zwałowej o znacznej miąższości, w nadkładzie poziomu wodonośnego.

Przeprowadzone badania składu chemicznego wód podziemnych potwierdzają związek klas jakości wód podziemnych ze stopniem ich podatności na zanieczyszczenia. Należy jednak mieć na uwadze, że przedstawiona mapa (ryc. 4) dotyczy podatności naturalnej wód podziemnych, która nie uwzględnia obecności ognisk zanieczyszczeń, lecz tylko wybrane parametry hydrogeologiczne, istotne ze względu na migrację potencjalnych zanieczyszczeń z powierzchni terenu do warstwy wodonośnej. Porównując jakość wód podziemnych ze stopniem ich podatności, można zauważyć przestrzenną zbieżność w północno-wschodniej części Kępy Puckiej, na południe Pucka. Punkty opróbowane w tym rejonie wykazały podwyższone zawartości fosforanów, którego potencjalnym źródłem mogą być pola uprawne. Na podstawie wykonanych wcześniej, w ramach projektu WaterPUCK, obliczeń przy wykorzystaniu kodu numerycznego HYDRUS-1D (Potrykus i in., 2018) stwierdzono, że pionowy czas przesączania się zanieczyszczeń konserwatywnych z powierzchni terenu do pierwszego poziomu wodonośnego wynosi w tym rejonie od 446 do 989 dni. Wskazuje to na relatywnie krótki czas migracji potencjalnych zanieczyszczeń do wód podziemnych (Q1), w porównaniu z czasem obliczonym za pomocą algorytmu MRT (mean residence time), określającego średni czas wymiany wilgotności objętościowej gleb i skał strefy aeracji przez infiltrujące wody opadowe (wysoki stopień podatności 5-25 lat) (ryc. 4).

Obecność antropogenicznie podwyższonych lub wysokich stężeń jonów $\mathrm{PO}_{4}^{3-}$ czy $\mathrm{K}^{+}$w wodach poziomu Q1 w warunkach od średniej do bardzo niskiej podatności (ryc. 4) wydaje się być mało prawdopodobne. Fosfor zawarty w glebie jest w niej słabym migrantem, tworzy nierozpuszczalne związki, które zwykle nie podlegają wymywaniu. Stąd, uważa się, iż nie stanowi zagrożenia dla jakości wód podziemnych (Macioszczyk, 1987; Flores-Lopez i in., 2013). Potas natomiast jest zatrzymywany przez rośliny lub minerały ilaste zawarte w środowisku skalnym, co wpływa na spadek jego stężenia (Macioszczyk, 1987). W płytkich wodach podziemnych obecność obydwu jonów w wysokich stężeniach można interpretować jako efekt oddziaływania znacznych ładunków fosforu wnoszonych w odchodach zwierząt podczas wypasu lub hodowli (Pietrzak, 2015).

Chlorki oraz azotany $\mathrm{NO}_{3}^{-}$należą do silnie migrujących składników wód podziemnych. Mogą być zatem transportowane od źródła zanieczyszczenia na dalekie odległości zgodnie z kierunkiem przepływu wody (Macioszczyk, 1987). Ich obecność w wodach podziemnych, nawet na obszarach 


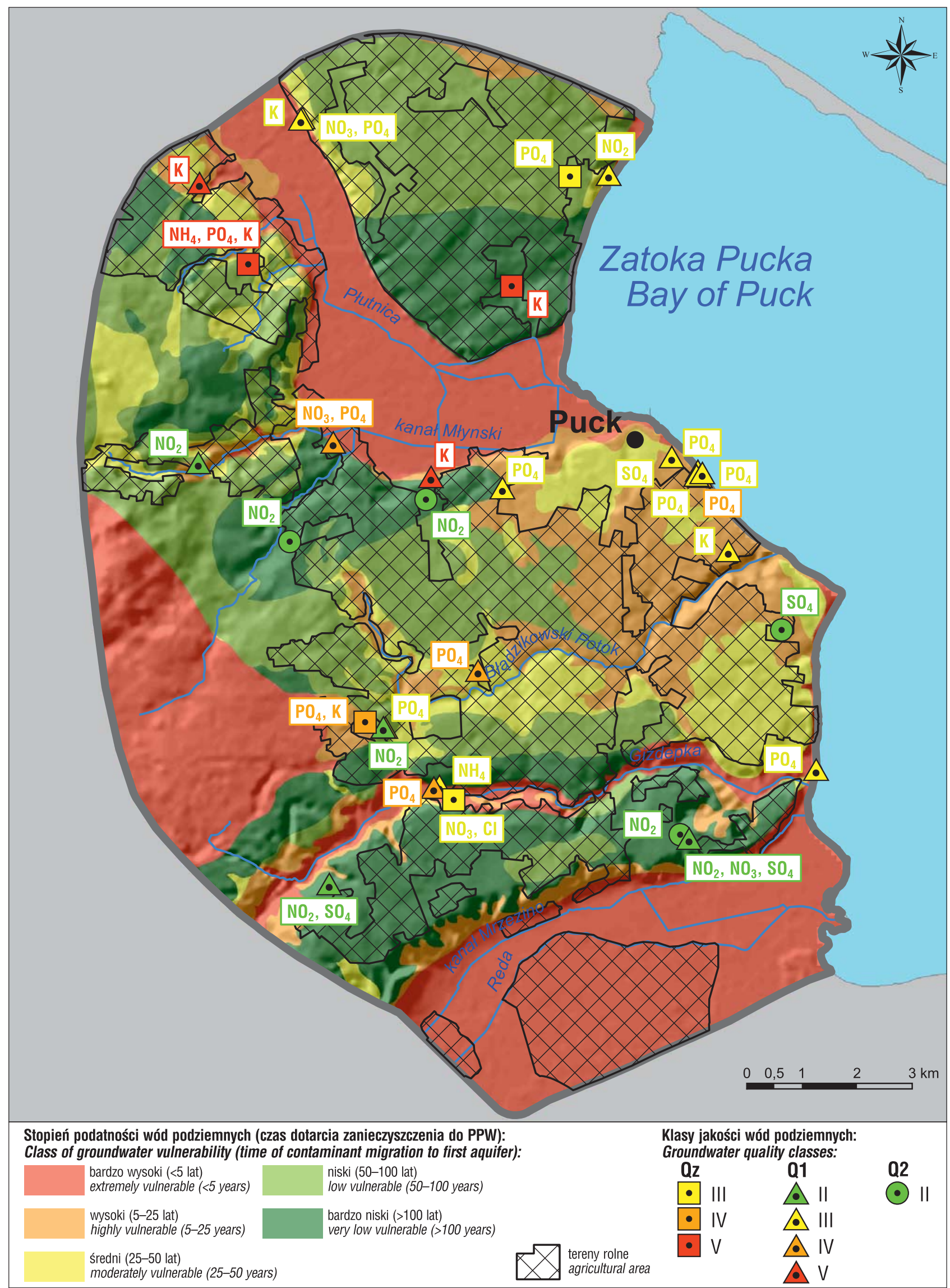

Ryc. 4. Rozkład przestrzenny podwyższonych i wysokich stężeń parametrów hydrogeochemicznych analizowanych w latach 2017-2019 w wydzielonych poziomach wodonośnych na tle mapy podatności wód podziemnych na zanieczyszczenie (na podstawie Pasierowskiej, 2007; Sierżegi, Nerkowskiego, 2010)

Fig. 4. Spatial distribution of increased concentrations of hydrogeochemical parameters in aquifers analyzed in years 2017-2019, presented on the map of groundwater vulnerability (based on Pasierowska, 2007; Sierżęga, Nerkowski, 2010) 
Tab. 3. Zestawienie statystyczne stężeń wybranych składników biogennych w badanych środowiskach wodnych (dane z lat 2017-2019) Table 3. Summary statistics for the selected nutrient concentrations in the investigated water bodies (sampling period 2017-2019)

\begin{tabular}{|c|c|c|c|c|c|c|}
\hline & & & $\begin{array}{l}\mathrm{NH}_{4}^{+} \\
{[\mathrm{mg} / \mathrm{l}]}\end{array}$ & $\begin{array}{c}\mathrm{NO}_{2}^{-} \\
{[\mathrm{mg} /[]}\end{array}$ & $\begin{array}{l}\mathrm{NO}_{3}^{-} \\
{[\mathrm{mg} / \mathrm{l}]}\end{array}$ & $\begin{array}{l}\mathrm{PO}_{4}^{3-} \\
{[\mathrm{mg} / \mathrm{l}]}\end{array}$ \\
\hline & & & \multicolumn{4}{|c|}{$\begin{array}{c}\text { min.--max. } \\
\text { mediana / median }\end{array}$} \\
\hline \multirow{3}{*}{$\begin{array}{l}\text { Wody podziemne } \\
\text { Groundwater }\end{array}$} & $\begin{array}{l}\text { lokalne wody } \\
\text { podziemne } \\
\text { local groundwater }\end{array}$ & $\begin{array}{l}\text { wody zawieszone } \mathrm{Qz} \\
\text { perched aquifer } Q z\end{array}$ & $\begin{array}{c}<0,01-3,56 \\
0,03\end{array}$ & $\begin{array}{c}<0,01-0,67 \\
0,04\end{array}$ & $\begin{array}{l}2,0-49,0 \\
26,0\end{array}$ & $\begin{array}{c}0,16-6,38 \\
0,50\end{array}$ \\
\hline & \multirow{2}{*}{\begin{tabular}{|l} 
wody podziemne \\
podlegające drenażowi \\
w zatoce Puckiej \\
groundwater \\
discharging to the Bay \\
of Puck \\
\end{tabular}} & $\begin{array}{l}\text { poziom wodonośny Q1 } \\
\text { upper aquifer Q1 }\end{array}$ & $\begin{array}{c}<0,01-3,32 \\
0,03\end{array}$ & $\begin{array}{c}<0,01-0,42 \\
0,01\end{array}$ & $\begin{array}{c}<0,1-92,0 \\
10,0\end{array}$ & $\begin{array}{c}0,10-3,06 \\
0,37\end{array}$ \\
\hline & & $\begin{array}{l}\text { poziom wodonośny Q2 } \\
\text { lower aquifer Q2 }\end{array}$ & $\begin{array}{c}<0,01-0,37 \\
0,14\end{array}$ & $\begin{array}{l}<0,01-0,09 \\
<0,01\end{array}$ & $\begin{array}{c}<0,1-1,0 \\
0,3\end{array}$ & $\begin{array}{c}0,09-0,49 \\
0,14\end{array}$ \\
\hline \multirow{3}{*}{$\begin{array}{l}\text { Wody } \\
\text { powierzchniowe }{ }^{1} \\
\text { Surface } \text { waters }^{I}\end{array}$} & \multicolumn{2}{|l|}{$\begin{array}{l}\text { Płutnica } \\
\text { Plutnica River }\end{array}$} & $\begin{array}{c}0,05-0,27 \\
0,16\end{array}$ & $\begin{array}{c}0,03-0,16 \\
0,10\end{array}$ & $\begin{array}{c}3,1-10,9 \\
3,8\end{array}$ & $\begin{array}{c}0,15-0,77 \\
0,40\end{array}$ \\
\hline & \multicolumn{2}{|l|}{$\begin{array}{l}\text { Błądzikowski Potok } \\
\text { Bładzikowski Stream }\end{array}$} & $\begin{array}{c}0,18-0,75 \\
0,16 \\
\end{array}$ & $\begin{array}{c}0,10-0,43 \\
0,13\end{array}$ & $\begin{array}{c}8,8-33,4 \\
10,4 \\
\end{array}$ & $\begin{array}{c}0,31-1,38 \\
0,31 \\
\end{array}$ \\
\hline & \multicolumn{2}{|l|}{$\begin{array}{l}\text { Reda } \\
\text { Reda River }\end{array}$} & $\begin{array}{c}0,04-0,19 \\
0,12\end{array}$ & $\begin{array}{c}0,03-0,13 \\
0,07\end{array}$ & $\begin{array}{c}1,7-6,7 \\
3,9\end{array}$ & $\begin{array}{c}0,15-0,74 \\
0,21\end{array}$ \\
\hline $\begin{array}{l}\text { Zatoka Pucka' } \\
\text { Bay of Puck }^{2}\end{array}$ & \multicolumn{2}{|c|}{$\begin{array}{l}\text { strefy podmorskiego drenażu wód podziemnych } \\
\text { submarine groundwater discharge }\end{array}$} & $\begin{array}{c}0,05-8,33 \\
0,81\end{array}$ & - & $\begin{array}{l}0,0-31,4 \\
0,35\end{array}$ & $\begin{array}{c}0,02-4,28 \\
0,72\end{array}$ \\
\hline
\end{tabular}

${ }^{1}$ Według Wojciechowskiej i in. (2019) / According to Wojciechowska et al. (2019).

${ }^{2}$ Według Szmczychy i in. (2020), w pobliżu miejscowości Osłonino, Puck, Swarzewo, Chałupy, Jurata, Hel / According to Szymczycha et al. (2020), in the vicinity of Osłonino, Puck, Swarzewo, Chatupy, Jurata and Hel.

o stosunkowo niskiej podatności, jest wskaźnikiem zanieczyszczenia.

Inny charakter wykazują jony amonowe i azotynowe. Azot $\mathrm{w}$ formie amonowej $\mathrm{NH}_{4}^{+}$jest charakterystycznym składnikiem wód w warunkach redukcyjnych i przejściowych, powstającym w procesie redukcji azotanów i azotynów oraz rozkładu materii organicznej w warunkach beztlenowych. W strefach o Eh ok. $100 \mathrm{mV}$ i poniżej naturalne stężenie $\mathrm{NH}_{4}^{+}$wzrasta nawet do kilku $\mathrm{mgNH}_{4} / \mathrm{l}$ (Witczak, Adamczyk, 1995), jest również typowym wskaźnikiem zanieczyszczenia. Jony te łatwo podlegają procesom sorpcji i wymiany jonowej na kontakcie z minerałami ilastymi, stąd ich migracja wodna jest ograniczona, a wysokie stężenia są związane tylko z bezpośrednim miejscem zanieczyszczenia. Natomiast azotyny $\mathrm{NO}_{2}^{-}$są przejściową formą przemian azotu $\mathrm{W}$ procesie utleniania $\mathrm{NH}_{4}^{+}$(nitryfikacji) oraz w procesie redukcji azotanów (denitryfikacji). Ich nietrwały charakter sprawia, że są ważnym wskaźnikiem zanieczyszczenia wód, głównie substancjami organicznymi w bezpośrednim sąsiedztwie ogniska zanieczyszczeń.

Naturalne pochodzenie siarczanów jest związane z procesami mikrobiologicznymi i rozkładem substancji organicznej. Środowisko wysoczyznowych osadów czwartorzędowych jest bardzo zasobne w zastoiskowe osady mułkowo-ilaste, zaś obszary pradolinne wyścielone są torfami, zawierającymi związki siarki pochodzące z rozkładu substancji organicznej. Jak wykazuje Górski (1981), w warunkach tlenowych związki siarki dwuwartościowej utleniają się, wzbogacając wody podziemne w łatwo rozpuszczalne siarczany.

Analiza występowania wyżej wymienionych wskaźników zanieczyszczeń na omawianym obszarze, budowy geologicznej oraz zagospodarowania terenu obecnie i w przeszłości pozwala na ocenę genezy zanieczyszczenia wód podziemnych. Uwagę zwraca fakt współwystępowania ze sobą różnych wskaźników zanieczyszczeń, np. obok jonów
$\mathrm{PO}_{4}^{3-}$ stwierdzono miejscami $\mathrm{SO}_{4}^{2-}, \mathrm{NO}_{3}^{-}, \mathrm{NH}_{4}^{+}$lub K $\mathrm{K}^{+}$. Na tej podstawie można przypuszczać, że podwyższone stężenia niektórych składników wód podziemnych są związane przede wszystkim z wywożeniem nawozów naturalnych (gnojowicy) na pola uprawne, obecnością ferm hodowlanych i zakładów rolniczych, w tym byłych PGR-ów i SHR-ów, dostarczaniem substancji biogennych $\left(\mathrm{PO}_{4}^{3-}, \mathrm{NH}_{4}^{+}\right)$, $\mathrm{K}^{+}$oraz $\mathrm{SO}_{4}^{2-}$ W odchodach zwierzęcych, nieuregulowaną gospodarką wodno-ściekową oraz, w mniejszym stopniu, z wykorzystaniem nawozów mineralnych.

W ramach projektu WaterPUCK były równocześnie prowadzone oznaczenia zawartości biogenów w ciekach powierzchniowych uchodzących do Zatoki Puckiej (Wojciechowska i in., 2019) oraz w strefach podmorskiego drenażu wód podziemnych, w obrębie Zatoki Puckiej (Szymczycha i in., 2020). Otrzymane wartości wykazywały sezonową zbieżność stężeń poszczególnych składników biogennych w badanych środowiskach wodnych, z kulminacją najwyższych wartości przypadającą na okres letni. Opisane w niniejszym artykule wyniki badań składu chemicznego wód podziemnych porównano z badaniami przeprowadzonymi przez Wojciechowską i in. (2019) oraz Szymczychę i in. (2020) (tab. 3). W dalszej analizie rozważano tylko poziomy wodonośne podlegające drenażowi w Zatoce Puckiej (poziomy wodonośne Q1 i Q2), a pominięto poziom wodonośny Qz, który w obrębie badanego terenu występuje lokalnie i nie bierze udziału w odpływie wód podziemnych do zatoki. Od górnego poziomu wodonośnego (Q1) jest on odizolowany kilkudziesięciumetrową warstwą utworów słabo przepuszczalnych (ryc. 1).

W wodach podziemnych odnotowano większy rozrzut pomierzonych wartości oznaczanych składników biogennych niż w wodach powierzchniowych oraz w strefach podmorskiego drenażu wód podziemnych. Wynika to z większej liczby wykonanych oznaczeń w wodach podziemnych oraz lokalizacji niektórych punktów badawczych wód pod- 
ziemnych w zasięgu oddziaływania lokalnego ogniska zanieczyszczeń, co bezpośrednio przełożyło się na uzyskanie skrajnie wysokich wartości stężeń. Obliczone wartości mediany dla składników biogennych w wodach podziemnych są na ogół niższe, bądź zbliżone w odniesieniu do median stężeń zarejestrowanych w ciekach powierzchniowych oraz w obrębie Zatoki Puckiej. Odnotowane stężenia $\mathrm{NH}_{4}^{+}$oraz $\mathrm{NO}_{2}^{-}$w wodach podziemnych są generalnie niższe niż w pozostałych punktach badawczych. Azotany zarówno w wodach podziemnych, jak i wodach powierzchniowych (w szczególności Błądzikowski Potok) charakteryzują się wyraźnie wyższymi wartościami w stosunku do badanych wód Zatoki Puckiej. Z kolei największe stężenia fosforanów odnotowano w opróbowanych strefach podmorskiego drenażu wód podziemnych, zaś w wodach podziemnych i ciekach wartości kształtowały się na zbliżonym poziomie. Istotny wpływ na obserwowane różnice stężeń biogenów w badanych środowiskach wodnych wynikają z ogólnie panujących w ich obrębie warunków (np. utleniająco-redukcyjnych, odczynu wód) oraz zachodzących procesów geochemicznych (np. rozpuszczanie minerałów, sorpcja), które dodatkowo zostały zwiększone przez sezonowy, lokalny dopływ zanieczyszczeń antropogenicznych.

Analiza składu chemicznego wód podziemnych na obszarze gminy Puck nie wskazuje, aby badane poziomy wodonośne stanowiły źródło zanieczyszczenia wód Zatoki Puckiej substancjami biogennymi. Punkty, w których stwierdzono wyższe stężenia azotanów lub/i fosforanów, występują lokalnie i mają charakter rozproszony. Obserwacje te są zbieżne $\mathrm{z}$ wynikami symulacji numerycznych przeprowadzonych $\mathrm{w}$ ramach projektu, w programie SWAT-MODFLOW dla różnych wariantów upraw oraz zróżnicowanego zagospodarowania terenu (Szymkiewicz $\mathrm{i}$ in., 2020). Obliczone stężenia azotanów w wodach podziemnych dopływających do Zatoki Puckiej nie przekraczają norm zawartości azotanów dla wód podziemnych I i II klasy (wody bardzo dobrej i dobrej jakości). Należy podkreślić, że zawartości azotanów mieszczące się w zakresie II klasy dotyczą tylko górnego poziomu wodonośnego Q1.

\section{WNIOSKI}

1. W toku przeprowadzonych badań stwierdzono, że zmiany jakości wód podziemnych są spowodowane dopływem do wód podziemnych zanieczyszczeń głównie o charakterze lokalnym, które powodują:

- wzrost stężeń niektórych składników w wodach podziemnych znajdujących się na płytszej głębokości, w stosunku do badań archiwalnych,

- inwersyjny pionowy rozkład stężeń związków azotu, siarczanów, chlorków, sodu, potasu, fosforanów i PEW,

- mozaikowy rozkład przestrzenny związków azotu, siarczanów, chlorków, sodu, potasu, fosforanów i PEW.

2. Zanieczyszczenie wód podziemnych dotyczy przede wszystkim wód poziomu zawieszonego Qz oraz górnego poziomu wodonośnego Q1 i występuje jedynie punktowo. Większość badanych parametrów w górnym poziomie wodonośnym (Q1) odpowiada I, II lub III klasie jakości, co wg klasyfikacji stanu chemicznego charakteryzuje dobry stan chemiczny (Rozporządzenie, 2019). Parametry odpowiadające IV i V klasie jakości stwierdzono lokalnie
W górnym poziomie. W dolnym poziomie wodonośnym (Q2) wszystkie badane parametry jakości wód odpowiadały I, II lub III klasie jakości, co charakteryzuje dobry stan chemiczny wód.

3. Zatoka Pucka jest obszarem drenażu wód podziemnych poziomów Q1 i Q2. Stwierdzono, że w wodach podziemnych dopływających do zatoki stężenia większości analizowanych parametrów hydrogeochemicznych nie przekraczają norm jakościowych dla I i II klasy (wody bardzo dobrej i dobrej jakości). Porównując skład chemiczny badanych wód podziemnych z wynikami badań cieków (Wojciechowska i in., 2019) i wód zatoki (Szymczycha i in., 2020), można zauważyć, że stężenia biogenów odnotowane w wodach podziemnych częściej występują w niższych stężeniach niż w ciekach powierzchniowych i w strefach podmorskiego drenażu.

4. Stwierdzone wskaźniki zanieczyszczeń wskazują, że główną przyczyną zanieczyszczenia wód podziemnych o charakterze lokalnym jest działalność bytowo-rolnicza. Potencjalne zanieczyszczenie może być skutkiem złego stanu sanitarnego gospodarstw rolnych i obejść gospodarskich, hodowli i wypasu zwierząt oraz składowania i stosowania nawozów naturalnych (np. obornika).

W artykule przedstawiono wyniki badań prowadzonych w ramach projektu finansowanego przez NCBiR pt. Modelowanie wplywu gospodarstw rolnych $i$ struktur użytkowania terenu zlewni na przyktadzie gminy Puck na jakość wód ladowych i morskich zlokalizowanych w strefie przybrzeżnej Morza Battyckiego - Zintegrowany Serwis informacyjno-predykcyjny WaterPUCK, nr BIOSTRATEG 3/343927/3/ NCBR/2017. Autorzy składaja serdeczne podziękowania Recenzentom naszego artykułu za pozytywne recenzje oraz wnikliwe, krytyczne i konstruktywne uwagi.

\section{LITERATURA}

AUGUSTOWSKI B. 1977 - Pomorze. PWN, Warszawa.

BISHOP J.M., CLENN C.R., AMATO D.W., DULAI H. 2017 - Effect of land use and groundwater flow path on submarine groundwater discharge nutrient flux. J. Hydrol., Reg. Stud., 11: 194-218.

BOLAŁEK J., FALKOWSKA L., KORZENIOWSKI K. 1993 - Hydrochemia Zatoki. [W:] Korzeniewski K. (red.), Zatoka Pucka. Gdańsk.

BURNETT W., AGGARWAL P., AURELI A., BOKUNIEWICZ H., CABLE J., CHARETTE M., KONTAR E., KRUPA S., KULKARNI K., LOVELESS A., MOORE W., OBERDORFER J., OLIVEIRA J., OZYURT N., POVINEC P., PRIVITERA A., RAJAR R., RAMESSURR., SCHOLTEN J., STIEGLITZ T., TANIGUCHI M., TURNER J. 2006 - Quantifying submarine groundwater discharge in the coastal zone via multiple methods. Sci. Tot. Environ., 367: 498-543. FLORES-LÓPEZ F., EASTON Z.M., GEOHRING L.D., VERMEULEN P.J., HADEN V.R., STEENHUIS T.S. 2013 - Factors affecting phosphorous in groundwater in an alluvial valley aquifer: Implications for best management practices. Water, 5 (2): 540-559.

FRĄCZEK E. 1998 - Objaśnienia do Mapy Hydrogeologicznej Polski w skali $1: 50$ 000, ark. Puck. Państw. Inst. Geol. Warszawa.

GAWLIKOWSKA E., SEIFERT K., PASIECZNA A., KWECKO P., TOMASSI-MORAWIEC H., KRÓL J. 2009 - Objaśnienia do Mapy geośrodowiskowej Polski w skali 1: 50 000, ark. Puck. Państw. Inst. Geol. Warszawa.

GÓRSKI J. 1981 - Kształtowanie się jakości wód podziemnych utworów czwartorzędowych w naturalnych warunkach oraz wymuszonych eksploatacją. Wyd. Inst. Kształ. Środ.

HERBICH P., NIDENTAL M., WOŹNICKA M. 2007 - Założenia metodyczne do opracowania warstw informacyjnych bazy danych GIS Mapy Hydrogeologicznej Polski 1:50 000 „Pierwszy poziom wodonośny wrażliwość na zanieczyszczenie i jakość wód”. WPH, 12: 253-261.

JANKOWSKA H. 1993 - Wody podziemne w utworach trzeciorzędowych i czwartorzędowych w regionie Puckim. [W:] Ekologia rejonów lądowych, przybrzeżnych i morskich Bałtyku - ochrona i kształtowanie. Sopot: 41-50. 
JANKOWSKA H., MATCIAK M., NOWACKI J. 1994 - Salinity variations as an effect of groundwater seepage through the seabed (Puck Bay, Poland). Oceanologia, 36 (1): 33-46.

JIAO J., POST V. 2019 - Coastal hydrogeology. Cambridge University Press

KROGULEC E. 2006 - Podatność wód podziemnych na zanieczyszczenia. [W:] Macioszczyk A. (red.), Podstawy hydrogeologii stosowanej. Wyd. Nauk. PWN.

KRYZA J., KRYZA H. 2006 - Analityczna i modelowa ocena bezpośredniego dopływu podziemnego do Bałtyku na terytorium Polski. Geologos, 10: $153-166$.

LEE C.M., JIAO J.J., LUO X., MOORE W.S. 2012 - Estimation of submarine groundwater discharge and associated nutrient fluxes in Tolo Harbour, Hong Kong. Sci. Tot. Environ., 433: 427-433.

MACIOSZCZYK A. 1987 - Hydrogeochemia. Wyd. Geol.

MACIOSZCZYK A. 1990 - Tło i anomalie hydrogeochemiczne. Metody badania, oceny i interpretacji. Wyd. SGGW-AR. Warszawa.

MATCIAK M., PRUSZKOWSKA-CACERES M., SZYMCZYCHA B. KOBOS J., KŁOSTOWSKA Ż., MISIEWICZ M., OWSIANNY P.M. 2020 - Dopływ wód podziemnych do Zatoki Puckiej. [W:] Bolałek J. (red.), Zatoka Pucka. Wyd. UG (w druku).

MOORE W. 2010 - The Effect of Submarine Groundwater Discharge on the Ocean. Ann. Rev. Mar. Sci., 2: 59-88.

NERKOWSKI P. 2010 - Objaśnienia do baza danych GIS Mapy Hydrogeologicznej Polski 1 : 50 000 - „Pierwszy Poziom Wodonośny wrażliwość na zanieczyszczenie i jakość wód”, ark. Rumia. Państw. Inst. Geol., Warszawa.

ORŁOWSKI R. 1998 - Objaśnienia do Mapy Hydrogeologicznej Polski w skali 1 : 50000 ark. Rumia. Państw. Inst. Geol., Warszawa.

PIEKAREK-JANKOWSKA H. 1994 - Zatoka Pucka jako obszar drenażu wód podziemnych. Wyd. UG.

PIEKAREK-JANKOWSKA H. 1996 - Hydrochemical effects of submarine groundwater discharge to the Puck Bay (southern Baltic Sea, Poland). Geograph. Pol., 67: 103-119.

PASIEROWSKA B. 2007 - Baza danych GIS Mapy Hydrogeologicznej Polski 1 : 50000 - „Pierwszy Poziom Wodonośny wrażliwość na zanieczyszczenie i jakość wód”, ark. Rumia wraz z objaśnieniami. Państw. Inst. Geol., Warszawa.

PIETRZAK S. 2015 - Fosforany w wodach gruntowych na terenach zajmowanych przez użytki zielone w Polsce. Woda-Środowisko-Obszary Wiejskie, 15 (3/51): 89-100.

POTRYKUS D., GUMUŁA-KAWĘCKA A., JAWORSKA-SZULC B. PRUSZKOWSKA-CACERES M., SZYMKIEWICZ A. 2018 Assessing groundwater vulnerability to pollution in the Puck region (denudation moraine upland) using vertical seepage method. $10^{\text {th }}$ Conference on Interdisciplinary Problems in Environmental Protection and Engineering EKO-DOK. Polanica-Zdrój. E3S Web of Conferences 44 00147.

PRUSZKOWSKA M. 2005 - Hydrogeologiczne uwarunkowania i jakość wód podziemnych piętra trzeciorzędowego na Kępie Swarzewskiej. Inż. Morska i Geotechnika, 5: 373-376.

ROZPORZADZENIE Ministra Gospodarki Morskiej i Żeglugi Śródlądowej z dnia 11 października 2019 r. w sprawie kryteriów i sposobu oceny stanu jednolitych części wód podziemnych. Dz.U. z 2019 r. poz. 2148 .

SIERŻĘGA P., NERKOWSKI P. 2010 - Baza danych GIS Mapy Hydrogeologicznej Polski 1 : 50000 - „Pierwszy Poziom Wodonośny wrażliwość na zanieczyszczenie i jakość wód”, ark. Puck. Państw. Inst. geol., Warszawa.

SLOMP C.P., VAN CAPPELLEN P. 2004 - Nutrient inputs to the coastal ocean through submarine groundwater discharge: controls and potential impact. J. Hydrol., 295: 64-86.

SZYMCZYCHA B., VOGLER S., PEMPKOWIAK J. 2012 - Nutrient fluxes via submarine groundwater discharge to the Bay of Puck, southern Baltic Sea. Sci. Tot. Environ., 438: 86-93.

SZYMCZYCHA B., KŁOSTOWSKA Ż., LENGIER M., DZIERZBICKA-GŁOWACKA L. 2020 - Significance of nutrient fluxes via submarine groundwater discharge in the Bay of Puck, southern Baltic Sea. Oceanologia, 62 (2): 117-125.

SZYMKIEWICZ A., POTRYKUS D., JAWORSKA-SZULC B., GUMUŁA-KAWĘCKA A., PRUSZKOWSKA-CACERES M., DZIERZBICKA-GŁOWACKA L. 2020 - Evaluation of the influence of farming practices and land use on groundwater resources in a coastal multiaquifer system in Puck region (northern Poland). Water, 12 (4): 1042.

WITCZAK S., ADAMCZYK A. 1995 - Katalog wybranych fizycznych i chemicznych wskaźników zanieczyszczeń wód podziemnych i metod ich oznaczania, t. II. Państw. Inspek. Ochr. Środ.

WOJCIECHOWSKA E., NAWROT N., MATEJ-ŁUKOWICZ K., GAJEWSKA M, OBARSKA-PEMPKOWIAK H. 2019 - Seasonal changes of the concentrations of mineral forms of nitrogen and phosphorus in watercourses in the agricultural catchment area (Bay of Puck, Baltic Sea, Poland). Water Supply, 19 (3): 986-994.

www.clc.gios.gov.pl

www.waterpuck.pl

Praca wpłynęła do redakcji 30.03.2020 r.

Akceptowano do druku 7.08.2020 r. 